\title{
Microplastic Occurrence in Marine Invertebrates Sampled from Kwazulu-Natal, South Africa in Different Seasons
}

\author{
O.A. Iwalaye $\dagger$, G.K. Moodley and D.V. Robertson-Andersson
}

Marine Biology, Aquaculture, Conservation Education and Ecophysiology (MACE) Laboratory, School of Life Sciences, University of KwaZulu-Natal Private Bag X54001, Durban, 4000, South Africa

†Corresponding author: O.A. Iwalaye; iwalayeoladimeji@gmail.com

Nat. Env. \& Poll. Tech. Website: www.neptjournal.com

Received: $17-02-2020$

Revised: 02-03-2020

Accepted: 02-05-2020

Key Words:

Microplastic

Feeding method

Dotilla fenestrata

Holothuria cinerascens

Pyura stolonifera

\begin{abstract}
The occurrence of microplastics in the environment, together with increasing temperatures as a result of climate change, has become a global concern. However, few reports are available on microplastic ingestion in lower benthic marine animals sampled from their natural environment during different seasons of the year. This study investigated microplastic uptake in Dotilla fenestrata (Hilgendorf 1869), Holothuria cinerascens (Brandt 1835) and Pyura stolonifera (Heller 1878) sampled from their natural environment during winter and summer. Animals sampled were cleaned of sand and attached animals and transported on ice to the laboratory. $D$. fenestrata, $H$. cinerascens (guts), and $P$. stolonifera (soft tissues) were digested in $10 \%$ potassium hydroxide $(\mathrm{KOH})$ solution for 24 hours at $60^{\circ} \mathrm{C}$ and analysed for microplastics. The per cent occurrences of microplastics found in sampled animals were more than $95 \%$ in both seasons, and fibres were the most predominant microplastic types found. Season significantly affect microplastic uptake in Dotilla fenestrata (t-test: t-value $=2.915$, df $=58, p=0.01$ ) while it had no effect in $H$. cinerascens and $P$. stolonifera sampled. A significantly higher number of microplastics were found in $D$. fenestrata than $H$. cinerascens (ANOVA HSD: $d f=2, p=008$ ) and $P$. stolonifera (ANOVA HSD: $d f=2, p=000$ ) in winter while $H$. cinerascens had a higher number of microplastics than $P$. stolonifera in summer (ANOVA HSD: $\mathrm{df}=2, p=002$ ). These results show that microplastic uptake in some ectotherms may be season-dependent and that feeding method impacts the accessibility of marine invertebrates to microplastics in their environment.
\end{abstract}

\section{INTRODUCTION}

The growing concern over the exponential increase in plastic production and its prevalence in the environment worldwide has increased over the last decade (Duis \& Coors 2016, Lusher et al. 2017). Improper disposal of plastics, poor management, accidental loss and degradation have resulted in the ubiquitous presence of microplastics $(<5 \mathrm{~mm})$ in the entire ecosystem (Au et al. 2017, Duis \& Coors 2016). Microplastics small size, varied densities and proliferation in the environment have made them readily available and accessible to a wide range of organisms (Tosetto et al. 2017). Increasing temperature due to climate change is another global concern (O'Brien \& Leichenko 2000). The world oceans are experiencing net warming (Bindoff et al. 2007) and the water temperature has profound influences on physiological and metabolic activities of ectotherms (Cossins \& Bowler 1987, Yukihira et al. 2000). Increased temperature will also speed up the disintegration of macroplastics to microplastics due to photochemical processes activated by ultraviolet (UV) light and result in increased microplastic concentration in the environment (Cao et al. 2017). Increased precipitation and heavy rainfall (Loo et al. 2015), extreme and frequent flood events (Woodward et al. 2010) associated with global climate change can facilitate plastics transport from land into the ocean. Increased wave action due to sealevel rise will increase the mechanical breakdown of larger plastic to microplastics (Vianello et al. 2013).

Some studies have documented microplastic uptake in marine invertebrates sampled from their natural environment. This includes decapod crustacean (Nephrops norvegicus) from Clyde Sea (Murray \& Cowie 2011), gooseneck barnacles (Lepas spp.) from the North Pacific Subtropical Gyre (Goldstein \& Goodwin 2013), mussels from Nova Scotia's Eastern shore (Mathalon \& Hill 2014), brown shrimp (Crangon crangon) from the Southern North Sea and channel area (Devriese et al. 2015), blue mussels (Mytilus edulis) and lugworm (Arenicola marina) from the French, Belgian and Dutch North Sea coastlines (Cauwenberghe et al. 2015). However, microplastic uptake in marine invertebrates at different seasons has not been investigated despite the possible influence of season on microplastic availability for uptake in the environment and ectotherms metabolic activities. This study investigates microplastics 
occurrence in Dotilla fenestrata, Holothuria cinerascens and Pyura stolonifera sampled from their natural environment at different seasons. Ecologically, benthic invertebrates such as filter and deposit feeders are vital components of food webs that support higher vertebrates (Sokolova \& Lannig 2008). Suspension feeding and filter-feeding animals $(H$. cinerascens and $P$. stolonifera) are said to be an essential link between the suspended phytoplankton and higher trophic levels in aquatic food chains (Riisgard \& Larsen 2010). Dotilla fenestrata as a basal consumer links detritus and primary producers with higher trophic levels (Vermeiren \& Sheaves 2015). Holothuria cinerascens are important prey to a vast array of predators such as sea stars, sea otters (Enhydra lutris) triton snails, crustaceans such as crabs and gastropods, fishes, some birds, turtles, marine mammals, and humans also consume sea cucumbers (Purcell et al. 2016). A great variety of predators such as polychaetes, crabs, gastropods, fish and other omnivores and carnivorous invertebrates, birds, and man feed on ascidians (Manriquez et al. 2016). Dotilla is a food source for many bird species and other animals inhabiting mangroves (Pereira \& Goncalves 2000).

\section{MATERIALS AND METHODOS}

Ethical approval: Ethical approval with protocol reference number AREC/069/016D for collection and experimentation of D. fenestrata was obtained from the University of KwaZulu-Natal ethics committee. Experimentation of Pyura stolonifera and Holothuria cinerascens did not require an ethics permit (AREC). However, all animals were collected according to the Department of Agriculture, Forestry, and Fisheries (DAFF) permit number (RES2017/71 and RES2018/101). Transportation and experimentation of sampled animals were done following the University of KwaZulu-Natal ethics requirements.

Sample collection: According to Durban weather chat, July and February are the coolest and warmest months in Durban (KwaZulu-Natal) (www.weather-and-climate. com). Thus, animals for winter and summer studies were collected in July and February respectively. During winter (July 2017) and summer (February 2018), 30 sea squirts and 30 sea cucumbers were collected at low tide from the intertidal zone of Park Rynie Beach $\left(30^{\circ} 19^{\prime} \mathrm{S}\right.$; $\left.30^{\circ} 44^{\prime} \mathrm{E}\right)$ located on the southern KwaZulu-Natal, on the east coast of South Africa. In the field, attached marine invertebrates and shells were carefully detached from sampled animals. Also, 30 crabs were collected at low tide by shovelling and handpicking from Durban harbour (29 $52^{\prime} \mathrm{S} ; 31^{\circ} 02^{\prime} \mathrm{E}$ ) on the east coast of KwaZulu-Natal, South Africa. The sites for animals' collection were chosen based on their abundance in these locations. The reason for the difference in sampling sites was because $H$. cinerascens and $P$. stolonifera are intertidal animals found in rocky shores attaching to rocks while $D$. fenestrata is found occupying intertidal sandy shores (Manzoor et al. 2016). To remove mud and debris, sampled animals were thereafter rinsed with seawater. They were immediately placed in ice to reduce metabolism and to prevent loss of microplastics through depuration (Lusher et al. 2017). Animals were transported to the laboratory at University of KwaZulu-Natal and kept in freezers $\left(-20^{\circ} \mathrm{C}\right)$ before digestion procedures.

Sample analysis: Prior to dissection and digestion, animals were rinsed several times in deionised water to remove any attached microplastics (Desforges et al. 2015). After dissection, sea cucumber (gut), sea squirt soft tissues (Cauwenberghe et al. 2015) and crab (with shell) due to their small size and ability to uptake microplastics into the gills (Watts et al. 2014) were weighed to the nearest $0.1 \mathrm{~g}$ (Lusher et al. 2017) and placed in clean glass honey jars. Individual animals were digested in $150 \mathrm{~mL}$ of $10 \% \mathrm{KOH}$ for $24 \mathrm{~h}$ at $60^{\circ} \mathrm{C}$ (Dehaut et al. 2016, Lusher et al. 2017). Thereafter, filtered hypersaturated $\left(140\right.$ g.L $\left.\mathrm{L}^{-1}\right)$ sodium chloride $(\mathrm{NaCl})$ solution was added to the digestate (Naidoo et al. 2015) to further float and separate microplastics from sand and chitin (Lusher et al. 2017). Other floatation methods reportedly used for separating microplastics from other materials in microplastics studies are sometimes expensive. Thus, the cost-effective method which involved the solution that is similar to that of the environment was used. Digestate was thoroughly stirred using a glass rod for a few minutes (Dehaut et al. 2016) and allowed to settle for a minimum of $72 \mathrm{~h}$. The supernatant containing floating plastics particles were vacuum-filtered onto 1.6 $\mu \mathrm{m}$ GF/A Filters. Each filter was placed into a new clean plastic petri dish, covered and labelled, and dried in the oven at $60^{\circ} \mathrm{C}$ for $24 \mathrm{~h}$. Petri dishes were removed from the oven and stored until further analyses.

To avoid cross-contamination of samples, glass honey jars, Petri dishes, forceps, scissors, and washable laboratory equipment used, were acid washed, rinsed with series of distilled and deionised water and kept in a covered container. Also, all dissections and sample preparation were done in a fume hood. Samples contamination with plastics fibre from clothing was avoided by wearing white laboratory safety equipment made of cotton. Also, procedural blanks were run concurrently during sample processing to identify contamination (Lusher et al. 2017). To check for potential airborne microplastics contamination, filter paper placed in a clean petri dish was exposed to the air during sample preparation and microscopic analysis (Kanhai et al. 2017).

For microplastics identification, each filter was analysed using a light microscope (Stereo Nikon ${ }^{\circledR}$ AZ100) at the University of KwaZulu-Natal Microscopy and Microanalysis Unit (MMU). Identified microplastics were counted and clas- 
sified into types (microbead, fragment, fibre, film and foam) using morphological features (Hidalgo-Ruz et al. 2012). Some of the identified microplastics (some of the minute microplastics could not be picked from the filter paper) were further subjected to a hot needle test (Lusher et al. 2017).

Statistical analysis: Statistical analysis was done using SPSS software (SPSS 2017: IBM version 25), and a test of significance was conducted using independent sample t-test and Analysis of Variance (ANOVA). All values (number of microplastics) were ranked to reach normality. One-sample Kolmogorov-Smirnov test was performed to check for normality and the p-value was considered significant at a $95 \%$ confidence interval $(p<0.05)$.

\section{RESULTS}

Microplastic abundance: The percentage (\%) occurrence of microplastics were: $100 \%$ in both summer and winter in D. fenestrata, $100 \%$ and $96.7 \%$ in summer and winter in H. cinerascens, and $96.7 \%$ and $100 \%$ in P. stolonifera in summer and winter, respectively (Table 1). The number of particles per individual ranged from 1-24 (7.57 \pm 1.13$)$ and
4-25 (12.07 \pm 1.06$)$ in D. fenestrata, $2-25(10.23 \pm 1.09)$ and $0-19(8.13 \pm 1.04)$ in $H$. cinerascens, and 0-19 (4.60 $\pm 0.67)$ and $1-14(3.57 \pm 0.51)$ in $P$. stolonifera in summer and winter respectively (Table 1 ). The total number of microplastics found in D. fenestrata in winter (362) were more than summer (227), while more microplastics were found in $H$. cinerascens and $P$. stolonifera in summer (307 and 138) than in winter (244 and 107) (Table 1). However, there was significant difference in mean microplastics found between seasons in $D$. fenestrata only (t-test: t-value $=2.915$, df $=$ $58, p=0.005$ ) while the mean microplastics found between seasons in $H$. cinerascens and $P$. stolonifera was not statistically different (t-test: $\mathrm{df}=58, p>0.05)$ (Fig. 1).

There was no difference between the overall total number of microplastics found in winter and summer (t-test: t-value $=0.516, \mathrm{df}=178, p=0.606$ ) (Fig. 2). However, there were differences between the number of microplastics found in sampled animals within each season (One-way ANOVA: winter, $\mathrm{F}_{(2,87)}=22.084, p=0.000$; summer, $\mathrm{F}_{(2,87)}=8.173, p$ $=0.001)$. In winter, the mean number of microplastics (12.07 \pm 1.06 ) found in $D$. fenestrata was greater than the mean number of microplastic $(8.13 \pm 1.04)$ found in $H$. cinerascens

Table 1: Percentage occurrence and the total number of microplastics found in the animals sampled in summer and winter.

\begin{tabular}{|c|c|c|c|c|c|c|}
\hline & Season & No. of sampled animals & No. of animals with MPs & $\%$ MPs occurrence & Total MPs & Range of MPs \\
\hline \multirow[t]{2}{*}{ D. fenestrata } & summer & 30 & 30 & 100 & 227 & $1-24$ \\
\hline & winter & 30 & 30 & 100 & 362 & $4-25$ \\
\hline \multirow[t]{2}{*}{ H. cinerascens } & summer & 30 & 30 & 100 & 307 & $2-25$ \\
\hline & winter & 30 & 29 & 96.7 & 244 & $0-19$ \\
\hline \multirow[t]{2}{*}{ P. stolonifera } & summer & 30 & 29 & 96.7 & 138 & $0-19$ \\
\hline & winter & 30 & 30 & 100 & 107 & $1-14$ \\
\hline
\end{tabular}

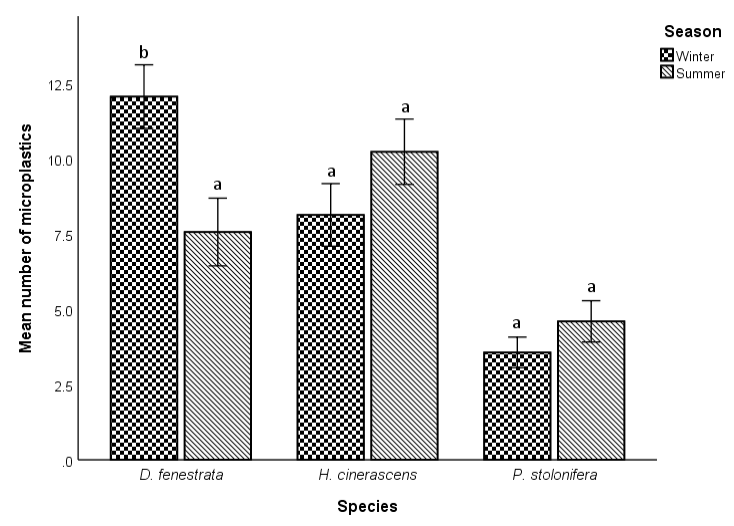

Fig.1: Mean $( \pm \mathrm{SE})$ number of microplastics found in $D$. fenestrata, $H$. cinerascens and $P$. stolonifera sampled in summer and winter.

[Means sharing the same alphabets are not significantly different at $p=$ 0.05 . Lower case $(a, b)$ denotes Independent t-test significant difference in means within specie $(n=60)$. Error bars indicate \pm 1 standard error (SE)].

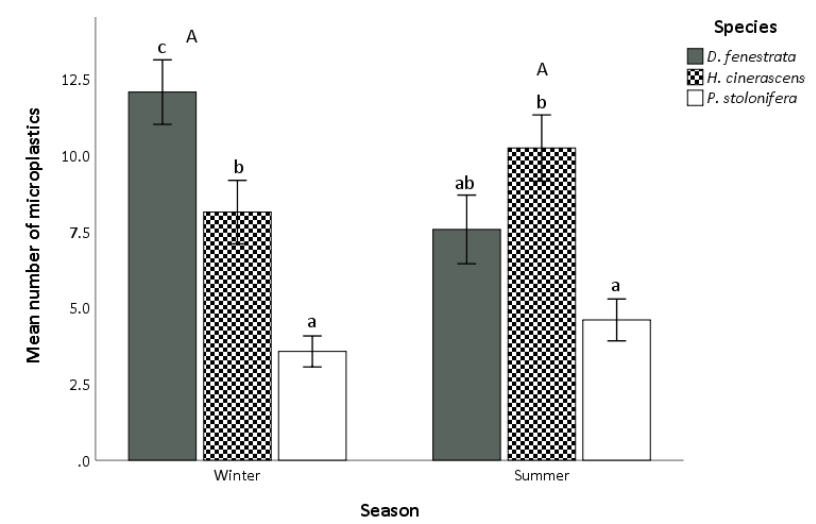

Fig. 2: Mean ( \pm SE) number of microplastics found in animals within and between seasons. [Means sharing the same alphabets are not significantly different at $p=0.05$. Lower case $(a, b)$ denotes Tukey HSD post hoc significant differences in mean within the season $(n=90)$, Upper case $(A, B)$ denotes Independent t-test significant difference in means between seasons $(n=180)$. Error bars indicate \pm 1 standard error $(\mathrm{SE})]$. 
(ANOVA HSD: $\mathrm{df}=2, \mathrm{p}=008)$ and $P$. stolonifera $(3.57$ \pm 0.51 ) (ANOVA HSD: $\mathrm{df}=2, \mathrm{p}=000$ ); and the number of microplastic $(8.13 \pm 1.04)$ found in $H$. cinerascens was greater than the number of microplastics $(3.57 \pm 0.51)$ found in P. stolonifera (ANOVA HSD: $\mathrm{df}=2, \mathrm{p}=002$ ). In summer, the mean number of microplastics $(10.23 \pm 1.09)$ found in $H$. cinerascens was higher than the mean number of microplastics $(4.60 \pm 0.67)$ found in $P$. stolonifera (ANOVA HSD: $\mathrm{df}=2, \mathrm{p}=000)$.

Microplastic characterization: The different types of microplastic identified in sampled animals included microbeads, fragments, fibres, films and foam (Fig. 3). Fibres were the most dominant microplastic type recorded in D. fenestrata $(73.1 \%$ and $68.0 \%)$ and $H$. cinerascens (56.7\% and 50\%) for summer and winter respectively while in P. stolonifera fibres dominated in summer (97.8\%) and fragments in winter (52.3\%) (Fig. 4). Microplastic fragments were the second dominant microplastic type found in $D$. fenestrata $(12.3 \% \& 27.6 \%)$ and $H$. cinerascens $(27.6 \%$ \& $34.0 \%$ ) in both seasons. Other types of microplastic found in these animals occurred in smaller quantities when compared with fibres and fragments.
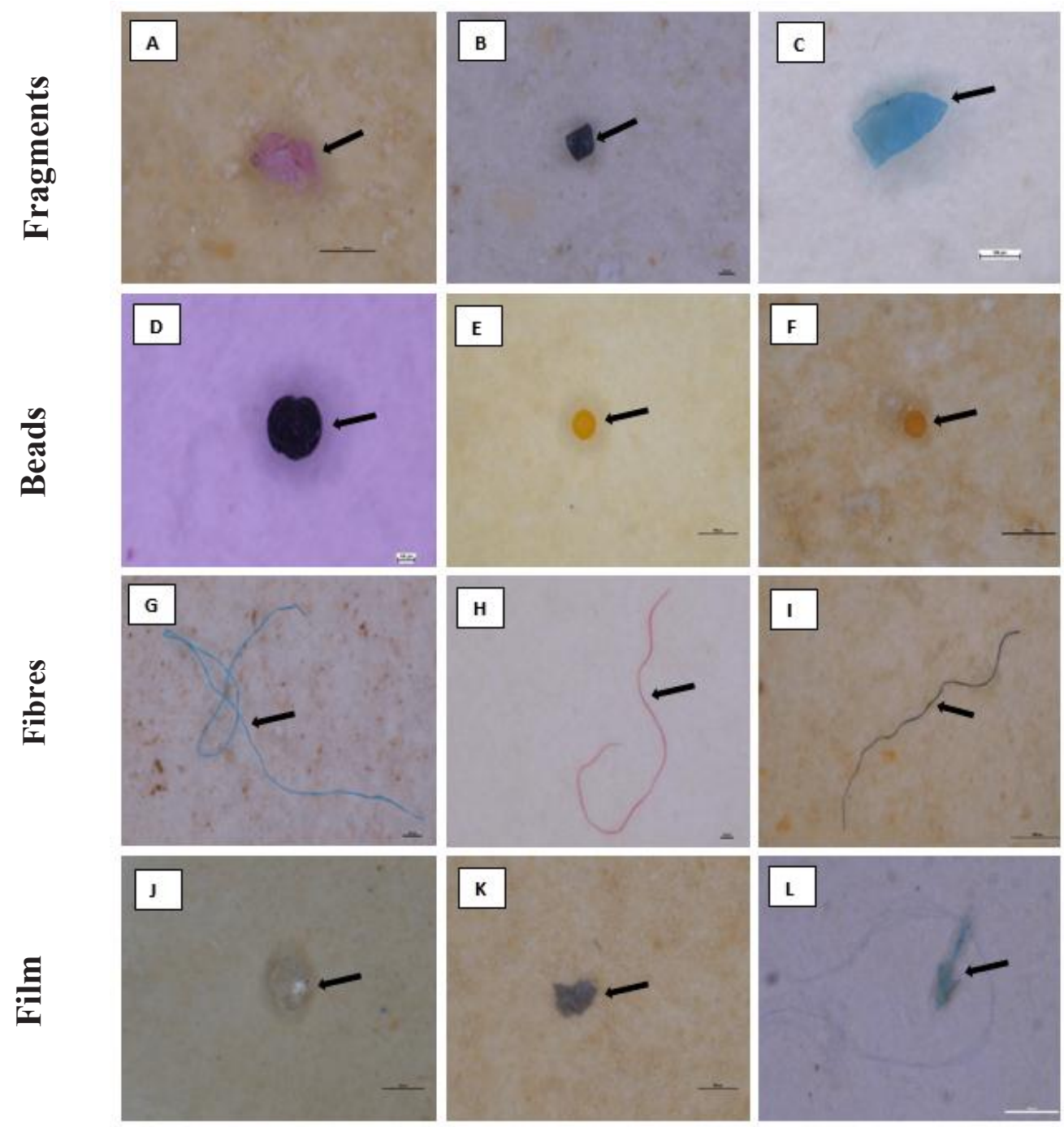

Fig. 3: Direct photographs of different microplastics (Black arrow) from the filter paper in $H$. cinerascens, $P$. stolonifera, and D. fenestrata collected in summer and winter from the southern and east coast of KwaZulu-Natal, South Africa. [(A) pink fragment- sc: $500 \mu \mathrm{m}$, (B) black fragment- sc: $100 \mu \mathrm{m}$, (C) blue fragment- sc: $100 \mu \mathrm{m}$, (D) black microbead- sc: $100 \mu \mathrm{m}$, (E-F) yellow microbead- sc: $500 \mu \mathrm{m}$, (G) blue fibre- sc: $100 \mu \mathrm{m}$, (H)- red fibre sc: $100 \mu \mathrm{m},(\mathrm{I})$ - black fibre - sc: $1000 \mu \mathrm{m},(\mathrm{J})$ - white film- sc: $500 \mu \mathrm{m},(\mathrm{K})-$ black film- sc: $500 \mu \mathrm{m}$, and (L)- blue film- sc: $500 \mu \mathrm{m}$. NB: $s c=s c a l e$. (Plastics were identified and classified as described by Hidalgo-Ruz et al. 2012)]. 


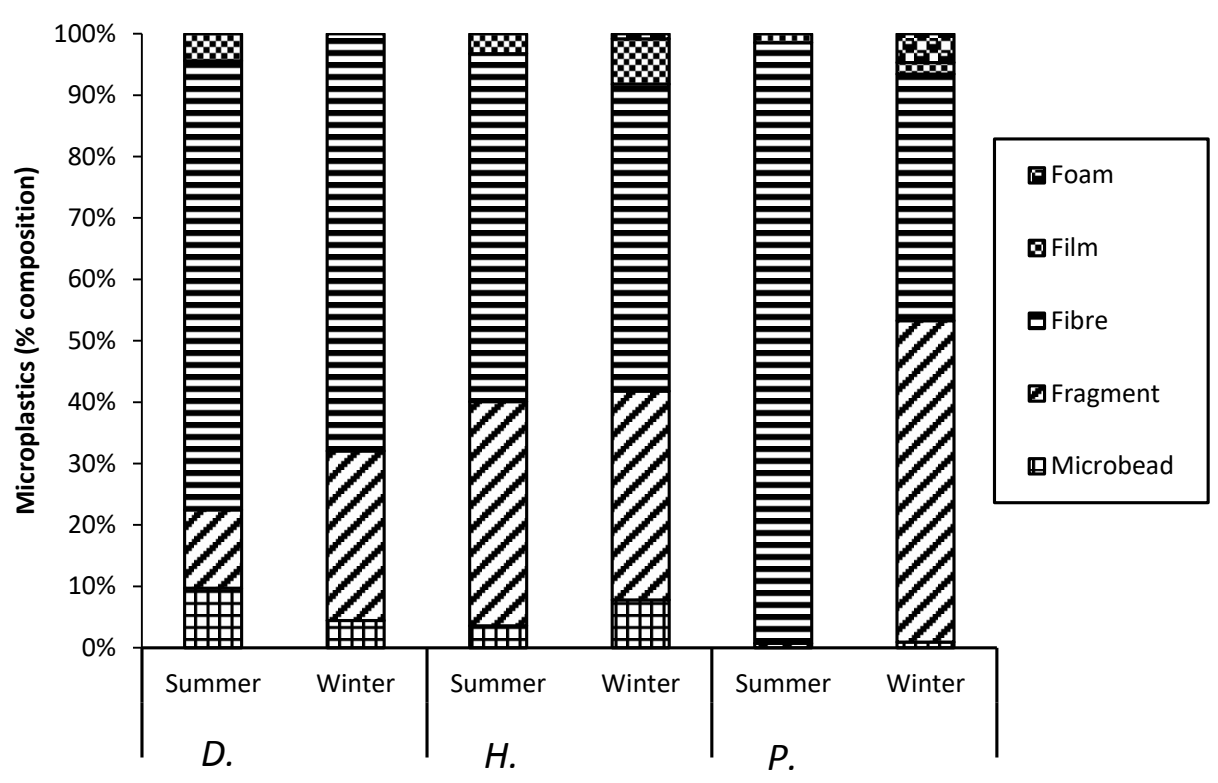

Fig. 4: Relative proportion of microplastic types (\%) found in sampled animals in summer and winter.

\section{DISCUSSION}

The differences recorded in the total number of microplastics found in sampled animals (Table 1 \& Fig. 2) may be due to the different feeding methods employed by the animals and sampling sites (Murphy et al. 2017). Rezania et al. (2018) reported that variation in the rates of microplastic ingestion by marine biota might be due to the difference in feeding behaviour and preferred habitat, among many other factors. Likewise, Taylor et al. (2016) in their study observed lower microplastic loads in filter feeders than deposit-feeders and it was reported that deposit feeders may be more vulnerable to microplastics ingestion (Brennecke et al. 2015) due to factors such as particle selection based on size or shape, density and abundance of microplastics in their environment, etc. Dotilla fenestrata is surface deposit feeders scooping sediment and sifting particulate organic matter such as algae, microbes, bacteria, diatoms, fungi, nematodes, detritus and ciliates from the inorganic matter (Gherardi et al. 2002, Khanyile 2012). Gherardi et al. (2002) identified five different genera of diatoms in the stomach of $D$. fenestrata, and Reisser et al. (2014) indicated that diatoms were the most colonizers of microplastics when compared with other groups of organisms collected from Australia inshore and offshore waters. This may be the reason why more microplastics were recorded in $D$. fenestrata since diatoms are one of the organic particulates consumed (Khanyile 2012) thereby, increasing the crabs' susceptibility to microplastics as they feed on diatoms. In addition, $D$. fenestrata sometimes uses a floatation feeding mechanism to float organic matter from the heavier inorganic matter (Davie et al. 2015). This could make $D$. fenestrata more susceptible to microplastics via ventilation mechanism process. It has been reported that shore crabs (Carcinus maenas) accumulated microplastic particles in their gills owing to the ventilation mechanism (Watts et al. 2014). Additionally, sediments may act as a reservoir for many microplastics, because close to $54 \%$ of plastics produced have a greater density than water, and the rapid bacterial colonies formation (biofouling) on the less dense microplastics would increase their density and make them sink (Watts et al. 2015). Furthermore, sediments were reported to be more stable than water (Nel et al. 2018), thus increasing the chances of $D$. fenestrata accessing more microplastics during feeding due to the stable (no wave action, water current, etc.) environment, unlike $H$. cinerascens and $P$. stolonifera which feed on the suspended particles in the water column.

It was observed in this study that more microplastics were found in $H$. cinerascens than $P$. stolonifera in both seasons although both were sampled from the same environment (Fig. 2). This may be due to the different feeding mechanisms employed by these animals; suspension/indiscriminate feeding ( $H$. cinerascens) versus filter/selective feeding $(P$. stolonifera) processes. $H$. cinerascens are suspension/deposit feeders spreading their tentacles to capture and feed on suspended particles found in the water column (Purcell et al. 2016) and on substratum to deposit feed (Roberts \& Bryce 1982), while $P$. stolonifera is sessile ciliary-mucus filter feeders that filter their food by trapping the suspended and 
re-suspended particulate matter in the water column (Shenkar et al. 2017). Our finding supports that of (Peters et al. 2017) who reported that selective (filter-feeding) invertebrates are less likely to ingest microplastics than the generalist (suspension-feeding) invertebrates. Desforges et al. (2015) also reported that indiscriminate (suspension) feeders in the water column are at risk of ingesting microplastics because they might mistake it for their natural food.

Furthermore, D. fenestrata were sampled from Durban harbour located in an urban centre which has increasingly been exposed to intense anthropogenic activities as a result of rapid human population growth, urbanisation and industrialization (Department of Environmental Affairs 2015), while $H$. cinerascens and $P$. stolonifera were sampled from Park Rynie located away from dense human population, urbanisation, and industrialisation. Park Rynie is located in Ugu District Municipality of KwaZulu-Natal, with the total district population of 753336 compared to Durban in the eThekwini district Municipality of KwaZulu-Natal with a total district population of 3702231 (Statistics South Afrie ca 2018). The eThekwini district population is almost five times the Ugu district population. Brennecke et al. (2015) reported a spatial association between level of microplastic pollution in water and nearness to urban centres. Factors such as population densities and high anthropogenic activities have a great influence on the microplastic abundance in aquatic environments (Horton et al. 2017). Previous studies have shown that high microplastic abundance is regularly found near urban areas with high human populations and activities (Horton et al. 2017). Noren \& Naustvoll (2010) also reported that industrial coastal areas are microplastic hotspots, placing organisms that inhabit urbanised coastal areas at potential risk for microplastic exposure (Au et al. 2017). This could be the reason for the higher number of microplastics recorded in $D$. fenestrata than in $H$. cinerascens and $P$. stolonifera because $D$. fenestrata were sampled from urban areas (Durban harbour), where microplastics are more abundant than the remote area from where $H$. cinerascens and $P$. stolonifera were sampled. Naidoo et al. (2015) reported that Durban harbour had the highest mean plastic particles compared to the other sites investigated. However, we suggest further studies to investigate and compare microplastic abundance in sediment and water samples from both sites.

The higher number of microplastics ingested by $D$. fenestrata in winter than summer (Fig. 1) may be because Durban receives less/no rainfall during winter. Therefore, in winter $D$. fenestrata can emerge and feed on well-drained sediment when the tide recedes (Bulcao \& Hodgson 2012) whereas rainfall might interrupt their feeding activities (personal observation) in summer. Bulcao \& Hodgson (2012) reported that sediment drainage is a vital factor that affects Dotilla activity. They further suggested the lack of sediment drainage to partly explain the inactivity of Dotilla in one of the days in their study. Hartnoll (1973) found that $D$. fenestrata activity was inhibited by heavy rain. Low temperatures that characterise winter will enable $D$. fenestrata to spend most of the time feeding at low tide while high temperature that characterises summer might make them feed less when the tide recedes as they tend to take cover in their burrow intermittently in avoidance of desiccation. On the contrary, a higher number of microplastics recorded (although not significant) in $H$. cinerascens and $P$. stolonifera during summer (Fig. 1) might be due to the increase in water temperature. Increased water temperature has been linked with increased metabolic activities in ectotherms (Cossins $\&$ Bowler 1987). This might cause the animals to feed more to compensate for the increasing body metabolism, therefore increasing their chances of ingesting microplastics. Rainfall and coastal flooding will facilitate the transport of macro and microplastics from land/dunes via urban runoff into marine environments, leading to higher concentrations of microplastics (Loo et al. 2015, Woodward et al. 2010) since Durban receives more rainfall during summer. According to Au et al. (2017) and Vianello et al. (2013), the increase in temperature and wave action due to rise in sea level/ storm surges will also facilitate the breakdown of macroplastics to microplastics leading to increased microplastics concentration. All the aforementioned will increase the bioavailability of microplastics to $H$. cinerascens and $P$. stolonifera during summer. The differences in the total number of microplastics recorded in sampled animals in different seasons, although insignificant in $P$. stolonifera and $H$. cinerascens, could be an indication of seasonal influence on microplastics uptake in marine invertebrates. However, studies involving sampling of animals in different seasons for a longer duration may help to further ascertain the influence of season on microplastics uptake.

Microplastics occurrence was recorded in over $95 \%$ of the animals sampled in both seasons in this study (Table 1) which agrees with the field study conducted by Cauwenberghe et al. (2015) who found that $100 \%$ of M. edulis and A. marina sampled had ingested microplastics. Li et al. (2015) found microplastics in all nine commercial bivalves collected from a fishery market in China. It was also reported that $83 \%$ of Nephrops norvegicus collected from Clyde Sea in the United Kingdom had ingested microplastics (Murray \& Cowie 2011). Goldstein \& Goodwin (2013) recorded $33.5 \%$ of lepadid barnacles sampled from North Pacific Subtropical Gyre had ingested plastics particles. Ferreira et al. 
(2016) reported plastic contaminants in $100 \%$ of Cynoscion acoupa sampled from Goiana estuary in South America. The multiple types of microplastic identified in this study are similar to findings of Li et al. (2015), where multiple types of microplastics were found in the tissue of bivalves ( $\mathrm{Sca}$ pharca suberenata, Tegillarca granosa, Meretrix lusoria, Cyclina sinensis, etc).

In this study, fibres were the most dominant microplastics encountered in sampled animals, followed by fragments (Figs. 3 \& 4). Previous studies also revealed fibres as the most dominant microplastics types followed by fragments (Devriese et al. 2015, Li et al. 2015, Neves et al. 2015, Woodall et al. 2014). Other types of microplastics found in this study were also reported in previous studies are fragments (Santillo et al. 2017), microbeads (Castaneda et al. 2014), and films (Santillo et al. 2017). Notably, more microplastics types were found in D. fenestrata during summer than winter, while more microplastic types were found in P. stolonifera and $H$. cinerascens in winter. This may be due to their availability in sediments and the water column during this season. The high number of fibres recorded in $D$. fenestrata in winter and $H$. cinerascens and $P$. stolonifera in summer can be linked to the overall total number of microplastics ingested by these animals in a particular season. It could be that fibres that were predominantly available in the water column to filter feeders (P. stolonifera) and suspension feeders $(H$. cinerascens) during summer might have settled in sediments during winter due to biofilm/ bacteria activities thus making them readily available to deposit feeders $(D$. fenestrata). The presence of microplastics in these animals is an indication of their potential to transfer microplastics to higher organisms along the food webs, including to humans. This is because they serve as prey to many higher trophic animals. Previous studies showed microplastic transfer from copepod and polychaete larvae to mysid shrimps (Setala et al. 2014), blue mussels to common shore crabs (Farrell \& Nelson 2013), and fish to lobsters (Murray \& Cowie 2011). According to Van Cauwenberghe \& Janssen (2014) seafood consumption could serve as a possible route of human exposure to microplastics as humans are top consumer in the food web. Lastly, a recent study reported nine different microplastic types in human stool screened for microplastics (Liebmann et al. 2018); the authors opined that humans unintentionally ingest plastics.

\section{ACKNOWLEDGEMENT}

We sincerely acknowledge the National Research Foundation for funding this project through the SA- Norway SANOCEAN grant (Grant number: UID 118752) and SA- Kenya grant (Grant number: UID 105816).

\section{REFERENCES}

Au, S.Y., Lee, C.M., Weinstein, J.E., Hurk, P.E. and Klaine, S.J. 2017. Trophic transfer of microplastics in aquatic ecosystems: Identifying Critical Research Needs. Integr, Environ, Asses., 13(3): 505-509

Bindoff, N., Willebrand, J., Artale, V., Cazenave, A., Gregory, J., Gulev, S., Hanawa K., Le Quere C., Levitus S., Nojiri Y., Shum C.K., Talley L. and Unnikrishnan A. 2007. Observations: oceanic climate and sea level. In: Solomon, S., Qin, D., Manning, M., Chen, Z., Marquis, M., Averyt, K.B., Tignor, M., Miller, H.L. (Eds.), Climate Change 2007: The Physical Science Basis. Contribution of Working Group I to the Fourth Assessment Report of the Intergovernmental Panel on Climate Change. Cambridge University Press, Cambridge, UK and NY, USA. pp. 385-432.

Brennecke, D., Ferreira, E.C., Costa, T.M.M., Appel, D., da Gama B.A.P. and Lenz, M. 2015. Ingested microplastics $(>100 \mu \mathrm{m})$ are translocated to organs of the tropical fiddler crab Uca rapax. Mar. Pollut. Bull., 96(1-2): 491-595.

Bulcao, C. and Hodgson, A.N. 2012. Activity and feeding of Dotilla fenestrata (Brachyura: Ocypodidae) in a warm, temperate South African estuary. Afr. J. Aquat. Sci., 37(3): 333- 338.

Cao, D., Wang, X., Luo, X., Liu, G. and Zheng, H. 2017. Effects of polystyrene microplastics on the fitness of earthworms in an agricultural soil. IOP Conf. Series: Earth Environ. Sci., 1: 2631.4.

Castaneda, R.A., Avlijas, S., Simard, M.A. and Ricciardi, A. 2014. Microplastic pollution in St. Lawrence River sediments. Can. J. Fish. Aquat. Sci., 71(12): 1767-1771.

Cauwenberghe, L.V., Claessens, M., Vandegehuchte, M.B. and Janssen, C.R. 2015. Microplastics are taken up by mussels (Mytilus edulis) and lugworms (Arenicola marina) living in natural habitats. Environ Pollut., 199: 10-17.

Cossins, A.R. and Bowler, K. 1987. Temperature Biology of Animals. Pub Chapman and Hall, London. pp. 339.

Davie, P.J., Guin, T.D. and Ng, P.K.L. 2015. Anatomy and functional morphology Of Brachyura. Koninklijke Brill NV, Leiden. Crustacea, 9C(71-2): 11-163.

Dehaut, A., Cassone, A.L., Frere, L., Hermabessiere, L., Himber, C., Rinnert, E., Riviere, G., Lambert, C., Soudant, P., Huvet, A. Duflos, G. and Paul-Pont, I. 2016. Microplastics in seafood: Benchmark protocol for their extraction and characterization. Environ Pollut., 215: 223-233.

Department of Environmental Affairs 2015. Durban Bay: Estuarine Management Plan. pp.54.

Desforges, J.W., Galbraith, M. and Ross, P.S. 2015. Ingestion of microplastics by zooplankton in the Northeast Pacific Ocean. Arch. Environ. Contam. Toxicol., 69: 320-330.

Devriese, L.I., van der Meulen, M.D., Maes, T., Bekaert, K., Paul-Pont I., Frere, L., Robbens, J. and Vethaak, A.D. 2015. Microplastic contamination in brown shrimp (Crangon crangon, Linnaeus 1758) from coastal waters of the Southern North Sea and Channel area. Mar. Pollut. Bull., 98: 179-187.

Duis, K. and Coors, A. 2016. Microplastics in the aquatic and terrestrial environment: Sources (with a specific focus on personal care products), fate and effects. (Review). Environ. Sci. Eur., 28: 2.

Farrell, P. and Nelson, K. 2013. Trophic level transfer of microplastic: Mytilus edulis (L.) to Carcinus maenas (L.). Environ Pollut., 177: 1-3.

Ferreira, G.V.B., Barletta, M., Lima A.R.A., Dantas, D.V., Justino, A.K.S, and Costa, M.F. 2016. Plastic debris contamination in the life cycle of Acoupa weakfish (Cynoscion acoupa) in a tropical estuary. ICES J. Mar. Sci., 73(10): 2695-2707.

Gherardi, F., Russo, S. and Lazzara, L. 2002. The function of wandering in the sand-bubbler crab, Dotilla fenestrata. J. Crustacean Biol., 22(3): 521-531.

Goldstein, M.C. and Goodwin, D.S. 2013. Gooseneck barnacles (Lepas 
spp.) ingest microplastic debris in the North Pacific Subtropical Gyre. Peer J., 1: e184.

Hartnoll, R.G. 1973. Factors affecting the distribution and behaviour of the Crab Dotilla fenestrata on East African Shores. Estuar. Coast. Mar. Sci., 1: 137-152.

Hidalgo-Ruz, V., Gutow, L., Thompson, R.C. and Thiel, M. 2012. Microplastics in the marine environment: A review of the methods used for identification and quantification. Environ. Sci. Technol., 46(6): 3060-3075.

Horton, A.A., Walton, A., Spurgeon, D.J., Lahive, E. and Svendsen, C. 2017. Microplastics in freshwater and terrestrial environments: Evaluating the current understanding to identify the knowledge gaps and future research priorities. Sci. Total Environ., 586: 127-141.

Kanhai, L.D., Officer, R., Lyashevska, O., Thompson, R.C. and O'Connor, I. 2017. Microplastic abundance, distribution and composition along a latitudinal gradient in the Atlantic Ocean. Mar. Pollut. Bull., 115(12): 307-314.

Khanyile, S.N. 2012. Salinity Tolerance and Osmoregulation in Several Subtropical Decapods. M.Sc. Thesis. pp. 84.

Li, J., Yang, D., Li, L., Jabeen, K. and Shi, H. 2015. Microplastics in commercial bivalves from China. Environ. Pollut., 207: 190- 195.

Liebmann, B., Koppel, S., Konigshofer, P. Bucsics, T., Reiberger, T. and Schwabl, P. 2018. Assessment of microplastic concentrations in human stool - final results of a prospective study. Available from: https://www.researchgate.net/publication/328702413_Assessment_ of_Microplastic_Concentrations_in_Human_Stool_Final_Results_ of_a_Prospective_Study (Accessed Dec. 23, 2018).

Loo, Y.Y., Billa, L. and Singh, A. 2015. Effect of climate change on seasonal monsoon in Asia and its impact on the variability of monsoon rainfall in Southeast Asia. Geosci. Front., 6(6): 817- 823.

Lusher, A.L., Welden, N.A., Sobral, P. and Cole, M. 2017. Sampling, isolating and identifying microplastics ingested by fish and invertebrates. Anal. Methods, 9: 1346.

Manriquez, P.H., Castilla, J.C., Ortiz, V. and Jara, M.E. 2016. Empirical evidence for large-scale human impact on intertidal aggregations, larval supply and recruitment of Pyura praeputialis around the Bay of Antofagasta, Chile. Austral Ecol., 41: 701-714.

Manzoor, R., Haider, S., Fatima, M. and Qari, R. 2016. Study on abundance, breeding and allometric growth of the ocypodidae crab Dotilla blanfordi in Karachi Coast, Pakistan. Int. J. Mar. Sci., 6(22): $1-14$.

Mathalon, A. and Hill, P. 2014. Microplastic fibers in the intertidal ecosystem surrounding Halifax Harbor, Nova Scotia. Mar. Pollut. Bull., 81: 69-79.

Murphy, F., Russell, M., Ewins, C. and Quinn, B. 2017. The uptake of macroplastic and microplastic by demersal \& pelagic fish in the Northeast Atlantic around Scotland. Mar. Pollut. Bull., 122(1-2): 353-359.

Murray, F. and Cowie, P.R. 2011. Plastic contamination in the decapod crustacean Nephrops norvegicus (Linnaeus, 1758). Mar. Pollut. Bull., 62(6): 207-1217.

Naidoo, T., Glassom, D. and Smit, A.J. 2015. Plastic pollution in five urban estuaries of KwaZulu-Natal, South Africa. Mar. Pollut. Bull., 101: 473-480.

Nel, H.A., Dalu, T. and Wasserman, R.J. 2018. Sinks and sources: Assessing microplastic abundance in river sediment and deposit feeders in an Austral temperate urban river system. Sci. Total Environ., 612: 950-956.

Neves, D., Sobral, P., Ferreira, J.L. and Pereira, T. 2015. Ingestion of microplastics by commercial fish off the Portuguese coast. Mar. Pollut. Bull., 101(1): 119-126.

Noren, F. and Naustvoll, F. 2010. Survey of microscopic anthropogenic particles in Skagerrak. 551 Report commissioned by Klima-og Forurensningsdirektoratet, Norway. Oceanogr. Mar. Biol. (An Annual Review), 54: 367-386.

O'Brien, K.L. and Leichenko, R.M. 2000. Double exposure: assessing the impacts of climate change within the context of economic globalization. Global Environ. Chang., 10: 221-232.

Pereira, M.A.M. and Goncalves P.M.B. 2000. A preliminary investigation of the effects of human physical disturbance on the ecology of the soldier crab Dotilla fenestrata (Crustacea, Ocypodidae) at Praia da Costa do Sol, Maputo. Presented at the 2nd National Conference on Coastal Areas Research. Maputo, pp. 27-29.

Peters, C.A., Thomas, P.A., Rieper, K.B. and Bratton, S.P. 2017. Foraging preferences influence microplastic ingestion by six marine fish species from the Texas Gulf Coast. Mar. Pollut. Bull., 124: 82- 88.

Purcell, S.W., Conand, C., Uthicke, S. and Byrne, M. 2016. Ecological roles of exploited sea cucumbers (An Annual Review). Oceanogr. Mar. Biol., 54: 20.

Reisser, J., Shaw, J., Hallegraeff, G., Proietti, M, Barnes, D.K.A., Thums, M., Wilcox, C., Hardesty, B.D. and Pattiaratchi, C. 2014. Millimetersized marine plastics: A new pelagic habitat for microorganisms and invertebrates. PLoS ONE 9(6): e100289.

Rezania, S., Park, J., Md Din, M. F., Mat Taib, S., Talaiekhozani, A., Kumar Yadav, K. and Kamyab, H. 2018. Microplastics pollution in different aquatic environments and biota: A review of recent studies. Mar. Pollut. Bull., 133: 191-208.

Riisgard, H.U. and Larsen, P.S. 2010. Particle capture mechanisms in suspension-feeding invertebrates. Mar. Ecol. Prog. Series., 418: 255-293.

Roberts, D. and Bryce, C. 1982. Further observation on tentacular feeding mechanisms in holothurians. J. Exp. Mar. Biol. Ecol., 59: 151- 163.

Santillo, D., Miller, K. and Johnston, P. 2017. Microplastics as contaminants in commercially important seafood species. Integr. Environ. Asses., 13: 516-521.

Setala, O. Fleming-Lehtinen, V. and Lehtiniemi, M. 2014. Ingestion and transfer of microplastics in the planktonic food web. Environ. Pollut., 185: 77- 83.

Shenkar, N., Gittenberger, A., Lambert, G., Rius, M., Moreira, Da Rocha, R., Swalla, B.J. and Turon, X. 2017. Ascidiacea World Database. http://www.marinespecies.org/ascidiacea (Accessed: July 25, 2017).

Sokolova, I. and Lannig, G. 2008. Interactive effects of metal pollution and temperature on metabolism in aquatic ectotherms: implications of global climate change. Clim. Res., 37(2-3): 181- 201.

Statistics South Africa. 2018. KwaZulu-Natal Citizen Satisfaction Survey: Analytical Report. Published by Statistics South Africa, Pretoria. pp. 124.

Taylor, M.L., Gwinnett, C., Robinson, L.F. and Woodall, L.C. 2016. Plastic microfibre ingestion by deep-sea organisms. Sci. Rep., 6(1): 33997.

Tosetto, L., Williamson, J.E. and Brown, C. 2017. Trophic transfer of microplastics does not affect fish personality. Anim. Behav., 123: 159-167.

Van Cauwenberghe, L. and Janssen, C.R. 2014. Microplastics in bivalves cultured for human consumption. Environ. Pollut., 193: 65-70.

Vermeiren, P. and Sheaves, M. 2015. Predictable habitat associations of four crab species across the low intertidal landscape of a tropical estuary over time. Estuar. Coast., 38: 285-295.

Vianello, A., Boldrin, A., Guerriero, P., Moschino, V., Rella, R., Sturaro, A. and Da Ros, L. 2013. Microplastic particles in sediments of Lagoon of Venice, Italy: First observations on occurrence, spatial patterns and identification. Estuar. Coast. Shelf S., 130: 54-61.

Watts, A.J.R., Lewis, C., Goodhead, R.M., Beckett, S.J., Moger, J., Tyler, 
C.R. and Galloway, T.S. 2014. Uptake and retention of microplastics by the shore crab Carcinus maenas. Environ. Sci. Technol., 48 (15): 8823-8830.

Watts, A.J.R., Urbina, M.A., Corr, S., Lewis, C. and Galloway T.S. 2015. Ingestion of plastic microfibers by the crab Carcinus maenas and its effect on food consumption and energy balance. Environ. Sci. Technol., 49(24): 14597-14604.

Woodall, L.C., Sanchez-Vidal, A., Canals, M., Paterson, G.L.J., Coppock, R., Sleight, V., Calafat, A. Rogers, A.D., Narayanaswamy, B.E. and
Thompson, R.C. 2014. The deep sea is a major sink for microplastic debris. Roy. Soc. Open Sci., 1(4): 140317-140317.

Woodward, G., Perkins, D.M. and Brown, L.E. 2010. Climate change and freshwater ecosystems: impacts across multiple levels of organization. Philos. T. R. Soc. B: Biol. Sci., 365(1549): 2093-2106.

Yukihira, H., Lucas, J.S. and Klumpp, D.W. 2000. Comparative effects of temperature on suspension-feeding and energy budgets of the pearl oysters Pinctada margaritifera and P. maxima. Mar. Ecol. Prog. Ser., 195: 179-188. 